\title{
Representasi Desain Indisch Trophic dalam Desain Interior Museum Pendidikan Dokter Indonesia di Surabaya
}

\author{
Thomas Ari Kristianto ${ }^{1}$, Caesario Ari Budianto ${ }^{2}$, Prasetyo Wahyudie ${ }^{3}$ \\ Laboratorium Sains Interior, Jurusan Desain Interior, Institut Teknologi Sepuluh Nopember \\ ${ }^{1}$ thomasjawa@prodes.its.ac.id, ${ }^{2}$ caesario101@gmail.com, ${ }^{3}$ prasetyo_wahyu@yahoo.com
}

\begin{abstract}
ABSTRAK
Mendesain interior museum dengan memanfaatkan bangunan yang sudah ada memerlukan metode yang khas. Terlebih lagi bila bangunan yang digunakan adalah bangunan lama dengan status cagar budaya. Selain aspek konservasi, konsep desain interior museum ini diarahkan untuk menghargai kondisi arsitektur asal. Dalam perjalanan proses desain, ditemukan bahwa gubahan representasi dari arsitektur asal bergaya "indisch tropic" dapat mewadahi konsep-konsep kurasional pajang museum, bahkan menghadirkan suasana penuh kenangan yang artistik dalam sajian modern.

Kata kunci: arsitektur Indisch tropis, interior, representasi, pajang.
\end{abstract}

\section{ABSTRACT}

Designing Museum's interior using existing building need some particular methods. Furthermore when the building use for that museum is an old building with heritage conservation status. Beside of conservation aspect, the concept of this museum's interior design conduct to respect to existing architectural building concept. Along design process, designer found that representative design start from "indisch style" could accomodated curative and displays, evenmore that could bring artistique memorable interior environment in modern appearance.

Keywords: Indisch tropis architecture, interior, representation, display.

\section{PENDAHULUAN}

Sejak didirikan tahun 1913, Fakultas Kedokteran Universitas Airlangga telah memiliki sejarah panjang. Ribuan dokter telah dididik dan banyak kejadian penting menyangkut dunia kedokteran, kesehatan dan bahkan peristiwa perjuangan bangsa Indonesia telah terjadi. Banyak pihak berpendapat, bahwa sejarah panjang, capaian dan kejadian-kejadian penting itu harus di wadahi dalam wujud museum. Museum juga dimaksudkan dapat menjadi sarana belajar untuk kemajuan di masa depan.

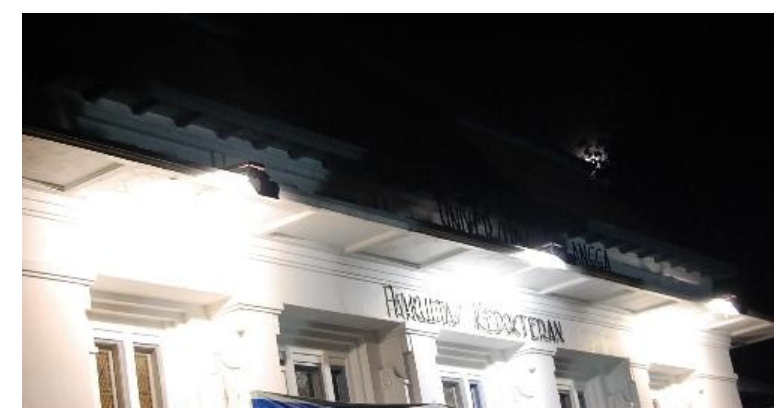

Gambar 1. Fakultas Kedokteran Universitas Airlangga Sumber: Dokumentasi Penulis (2013) 
Dalam rangka memperingati 100 tahun berdirinya Fakultas Kedokteran Universitas Airlangga, dibentuklah Panitia Peringatan 100 tahun Pendidikan Dokter di Surabaya. Kepanitiaan besar terdiri dari unsur Ikatan Alumni Fakultas Kedokteran Universitas Airlangga, selanjutnya disebut FK Unair, Civitas akademika FK Unair, dan unsur Ikatan Dokter Indonesia. Salah satu target capaian panitia ini adalah membuat Museum Pendidikan Dokter Indonesia di Surabaya. Panitia memberi tugas tim ITS untuk melakukan perancangan interior museum tersebut. Panitia juga menugaskan beberapa civitas akademika untuk menjadi nara sumber bagi tim ITS.

Panitia berunding dengan pihak FK Unair dan disepakatilah bahwa museum akan menempati sayap barat, gedung utama Kampus A Universitas Airlangga, yang saat itu ditempati bagian Farmasi Kedokteran FK Unair. Kordinasi pemindahan bagian merupakan fase yang tidak mudah dan memerlukan waktu beberapa minggu. Gedung tersebut berlokasi di gerbang utama area Kampus A dan dapat dilihat langsung dari jalan raya Darmahusada.

Pekerjaan rancang interior museum meliputi:

1. Riset dasar tentang sejarah FK.

2. Riset kondisi gedung lokasi.

3. Penggubahan beberapa alternatif alur kisah display.

4. Penentuan alur display.

5. Pencarian dan pemilihan materi pajang berdasarkan alur kisah (kurasi).

6. Restorasi materi.

7. Modifikasi minimal tampak materi sesuai konsep desain display.

8. Konsep dan Desain interior.

9. Desainkomunikasi visual, signage.

10.Penataan utilitas.

11.Pengaturan pencahayaan.

12.Pengaturan penghawaan mekanis.

13.Desain furnitur dan vitrin display.

14.Desain materi film dan multimedia.

Pekerjaan riset dan desain dilaksanakan dalam 70 hari kalender. Riset gedung lokasi dilakukan dengan cara dokumentasi, pengukuran lapangan, bersamaan dengan pemeriksaan kondisi arsitektur struktur dan non struktur. Bangunan sayap barat kampus A FK Unair juga menyimpan sejarah panjang. Banyak berperan sebagai sarana belajar, berorganisasi dan berkonsolidasi selama masa perjuangan kemerdekaan. Saat ini gedung tersebut sudah berkategori bangunan cagar budaya.

Riset materi dilakukan dengan melihat dan memilah langsung materi yang sebagian telah tersimpan di perpustakaan FK Unair. Metoda lain adalah wawancara dengan berbagai sumber, diantaranya dengan beberapa dokter senior. Dua diantaranya adalah penggagas mula museum FK, yakni Prof. DR.dr. Indropo Aguzni dan Prof. DR. dr. Sentot Moestajab Soeatmadji. Dua pendidik senior ini telah merintis dikumpulkannya ribuan materi sebagai bahan koleksi. Salah satu yang terpentinga adalah dokumen Surat Keputusan (besluit) Gubernur Hindia Belanda nomor 365 tentang pembentukan Nederlandsch Indische Artsen School (NIAS) atau Sekolah Kedokteran Hindia Belanda pada 1 Juli 1913. Berdasarkan besluit tersebut, NIAS mulai menerima mahasiswa pada 15 September 1013.

Sejak berdiri, Nederlandsch Indische Artsen School (NIAS) sudah mendidik dan meluluskan ribuan dokter. Sebagai salah satu institusi pendidikan dokter tertua di Indonesia (bersama FK Universitas Indonesia), FK Unair mendidik dan terus berusaha memenuhi rasio kecukupan dokter di Indonesia yang belum tercapai hingga tahun 2016 ini. Institusi 


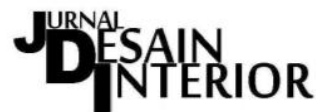

Vol. 1, No. 2, Desember, 2016, ISSN 2527 - 2853

pendidikan ini juga berperan menjadi bagian dari perjuangan kemerdekaan Negara Indonesia. Para dokter/ dosen berperan langsung sebagai pelaku sejarah perjuangan kemerdekaan. Diantaranya adalah Dokter Soetomo dan kelompok intelektual pergerakan yang sempat mengajar di FK Unair.

Dari sudut tinjau kesejarahan, bangunan, laboratorium dan fasilitasnya, sistem pendidikan, pengajar, manajemen, mahasiswa, alumni, riset, kegiatan mahasiswa memiliki rentang peran yang panjang sejak didirikan oleh pemerintah Kolonial Belanda. Diawali berada di bawah manajerial Belanda, berganti dalam tekanan dan model manajemen Jepang, berganti menjadi asset berharga Republik Indonesia yang masih muda, hingga mencapai kestabilan dan kemajuan dalam masa perguruan tinggi negeri. Mencapai statusnya sebagai Fakultas Kedokteran dengan peminat tertinggi di Indonesia, dan mencapai akreditasi internasional. Perjalanan panjang tersebut perlu didokumentasikan, dan disajikan dengan runtut dan menarik.

Sebagian besar materi dokumentasi tersimpan di perpustakaan FK Unair, di kantor fakultas dan di rumah sakit Dr Sutomo Surabaya. Sebagian lain materi dikumpulkan dari rumah-rumah para dokter senior. Materi dokumentasi dua dimensi diantaranya foto, piagam, besluit, gambar dll. Materi tiga dimensi berupa buku, peralatan laboratorium, busana wisuda, peralatan medis, barang-barang personal milik pelaku sejarah, hasil riset dll.

\section{A. Permasalahan}

Beberapa masalah dalam perancangan:

1. Status cagar budaya bangunan eksisting museum, sehingga tidak diperbolehkan merubah arsitektur secara drastis.

2. Luasan ruang yang terbatas dibandingkan jumlah materi koleksi.

3. Banyaknya materi pamer yang harus dikumpulkan, ditelaah dan diseleksi.

4. Informasi tentang benda koleksi yang terbatas.

5. Banyak ragam bentuk materi koleksi, sehingga mempengaruhi tipikal model display.

6. Tidak adanya benda besar/gigantis yang berpotensi menjadi penarik perhatian utama pengunjung.

7. Tampilan visual materi di mata awam perlu dibuat lebih menarik.

8. Sesuai fungsi konservasi, banyak sekali benda koleksi yang harus disimpan dengan aman dan awet.

9. Penambahan kafe sebagai fungsi pendukung museum, dalam kondisi terbatasnya ruang.

\section{B. Tujuan Perancangan}

Proses riset yang berujung pada perancangan bertujuan:

1. Menghasilkan desain interior yang sesuai dengan kondisi arsitektur eksisting bangunan cagar budaya.

2. Menghasilkan desain interior yang memiliki beragam model display untuk beragam tipikal koleksi materi.

3. Menghasilkan desain interior yang mampu memenuhi kebutuhan dasar museum bersangkutan dengan materi koleksi, yaitu konservasi dan preservasi .

4. Menghasilkan desain interior yang mampu memenuhi kebutuhan dasar museum bersangkutan dengan riset riset kedokteran yang sedang dilakukan, yaitu edukasi . 
Thomas Ari Kristianto, Caesario Ari Budianto, Prasetyo Wahyudie

Representasi Desain Indisch Trophic dalam Desain Interior Museum Pendidikan Dokter Indonesia di Surabaya

5. Menghasilkan desain interior yang mampu memenuhi kebutuhan tambahan museum bersangkutan eksistensi profesi kedokteran.

6. Menghasilkan desain interior yang berfungsi rekreasi pula sebagai obyek wisata pendidikan baru di Surabaya.

7. Menghasilkan desain yang memenuhi kaidah interior yang aman, nyaman, baik dan menarik.

8. Menghasilakan desain interior yang memenuhi beberapa kaidah minimal di bidang utilitas, fisika bangunan dan estetika.

\section{Arsitektur Gedung Eksisting Lokasi Museum}

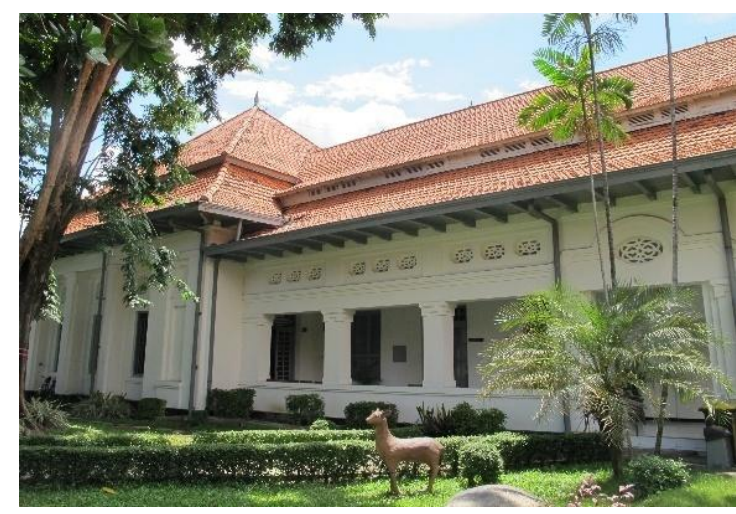

Gambar 3. Kondisi Arsitektur Eksisting Gedung Sayap Barat FK Unair.

Sumber : Dokumentasi Penulis (2013)

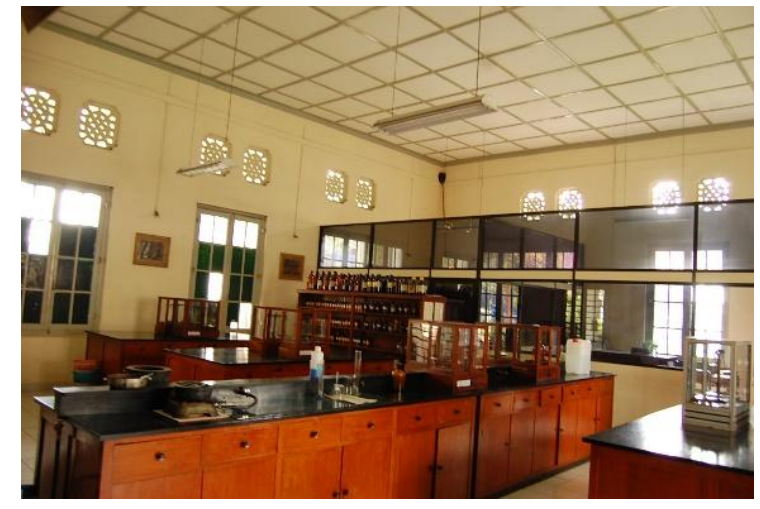

Gambar 4. Kondisi Eksisting Interior. Sumber : Dokumentasi Penulis (2013)

Sayap barat gedung utama FK Unair ini dibangun tahun 1921-1922. Dirancang oleh Wiemans dari BOW, bagian dari Departemen Pekerjaan Umum milik pemerintah kolonial Belanda. Posisi gedung membujur utara-selatan dengan arah hadap dominan ke timur. Gaya arsitektur adalah indische tropic. Sebuah gaya arsitektur yang diadaptasi para arsitek kolonial Belanda yang sudah memperhatikan kondisi iklim tropis Hindia Belanda pada masa itu. Kondisi iklim, dalam hal ini adalah kota Surabaya yang dimaksud:

1. Masuk zona tropis lembab.

2. Dua musim.

3. Kelembaban udara relatif selalu tinggi, sering diatas $97 \%$.

4. Suhu udara tinggi $24-36^{\circ} \mathrm{C}$.

5. Curah hujan tinggi, gradien arah titik hujan vertikal hingga sedikit miring.

6. Kecepatan angin cenderung rendah, arah datang angin terbanyak dari timur, timur laut dan tenggara.

7. Durasi penyinaran matahari 11-12,5 jam perhari.

8. Muka air tanah dangkal.

Antisipasi kondisi iklim tropis tersebut dapat dilihat dari rancangan arsitektur bangunan:

1. Tipikal bangunan tipis satu lapis, sehingga suatu ruang utama memiliki sedikitnya dua muka bangunan. Dengan demikian aliran udara penghawaan alami dapat dialirkan lewat ventilasi silang.

2. Atap bangunan cukup tinggi sehingga volume ruang dalam cukup besar.

3. Atap bangunan berkemiringan di atas $20^{\circ}$, untuk mengantisipasi beban air hujan. 
4. Ruang atas plafon bervolume besar untuk menjebak udara panas tidak banyak turun ke ruang.

5. Dinding tebal untuk penyimpan panas.

6. Jendela dan bukaan lain (venestrasi) berjumlah banyak dan berukuran besar untuk mengalirkan udara dan mengurangi kelembaban. Arah hadap ventilasi di semua sisi bangunan untuk mengantisipasi perubahan arah angina.

7. Terdapat teras dan koridor sebagai ruang luar untuk penyaring panas.

8. Berelevasi lantai di atas $30 \mathrm{~cm}$ di atas elevasi 0 tanah.

9. Estetika bangunan menghasilkan komposisi arsitektur yang anggun dan berwibawa, sesuai fungsi aslinya sebagai fasilitas pendidikan.

Dengan kondisi di atas, perancangan interior berangkat dari kondisi eksisting arsitektur kolonial bergaya Indische Tropic tersebut. Komposisi desain didasarkan pada komposisi desain arsitektur.

\section{METODE PRA DESAIN}

Tahapan pradesain yang dilakukan meliputi:

\begin{tabular}{|c|c|}
\hline \multirow{2}{*}{ T O R } & Penjelasan TOR dari Fakultas Kedokteran Unair \\
\hline & Penjelasan TOR dari panitia 100th FK Unair \\
\hline \multirow{5}{*}{$\begin{array}{l}\text { PENGUMPULAN } \\
\text { DATA }\end{array}$} & Data sejarah koleksi yang sudah dimiliki. \\
\hline & Data departemen FK dan proses pendidikan dokter. \\
\hline & Data sejarah FK Unair \\
\hline & Data sejarah bangunan gedung A kampus Universitas Airlangga \\
\hline & Data umum kebutuhan museum \\
\hline \multirow{5}{*}{$\begin{array}{l}\text { STUDI } \\
\text { EKSISTING } \\
\text { KOLEKSI } \\
\text { EKSISTING }\end{array}$} & Dokumentasi koleksi eksisting \\
\hline & Pendataan dan pengklasifikasian koleksi eksisting \\
\hline & Penomoran koleksi eksisting \\
\hline & $\begin{array}{l}\text { Analisa dan diskusi tentang koleksi dalam rangka menyusun skenario pajang koleksi yang } \\
\text { memungkinkan. }\end{array}$ \\
\hline & Perawatan koleksi \\
\hline \multirow{4}{*}{$\begin{array}{l}\text { STUDI } \\
\text { EKSISTING } \\
\text { BANGUNAN }\end{array}$} & Pengukuran \\
\hline & Pengamatan bangunan dengan lingkungan sekitar \\
\hline & Pemeriksaan kondisi bangunan \\
\hline & Pengamatan kasar kondisi iklim mikro \\
\hline \multirow{3}{*}{$\begin{array}{l}\text { KURATORIAL } \\
\text { /SKENARIO }\end{array}$} & Studi sejarah pendidikan dokter Surabaya \\
\hline & Penyusunan 2 alternatif rencana pajang museum \\
\hline & Pembuatan skenario film pendek pendukung pajang. \\
\hline \multirow[t]{3}{*}{ KONSEP } & Penyusunan konsep interior dan sistem pajang \\
\hline & Penyusunan konsep komunikasi visual \\
\hline & Perencanaan pencahayaan, sirkulasi, material dll. \\
\hline \multirow{3}{*}{ PROGRAMING } & Studi penerapan alur koleksi \\
\hline & Studi sirkulasi pengunjung dan pengelola \\
\hline & Studi hubungan antar ruang \\
\hline
\end{tabular}

Gambar 2. Metode Desain Interior.

Sumber : Konstruksi Penulis (2013)

\section{PROSES DESAIN}

Desain interior sangat mementingkan aliran/sirkulasi pengunjung. Hal ini akan diikuti dengan alur cerita materi. Dasar konsep alur display adalah linier plus. Pengunjung diarahkan untuk menikmati materi sesuai alur dari jaman ke jaman, ditambah aksen beberapa fakta sejarah menarik diantara alur linier yang panjang. 
Thomas Ari Kristianto, Caesario Ari Budianto, Prasetyo Wahyudie

Representasi Desain Indisch Trophic dalam Desain Interior Museum Pendidikan Dokter Indonesia di Surabaya

Desain bentukan display mengacu pada aliran arus yang direncanakan. Komposisi visual interior; dimensi, garis, warna, bidang, ornamentasi mengacu pada transformasi desain arsitektur Indische Tropic.

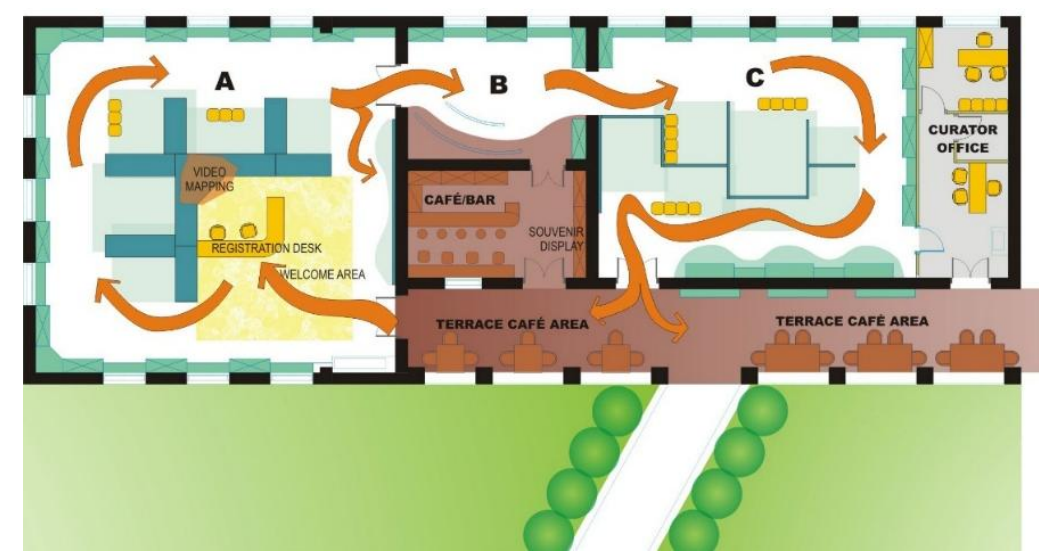

Gambar 5. Rencana Alur Sirkulasi Pengunjung. Sumber: Konstruksi Penulis (2013)

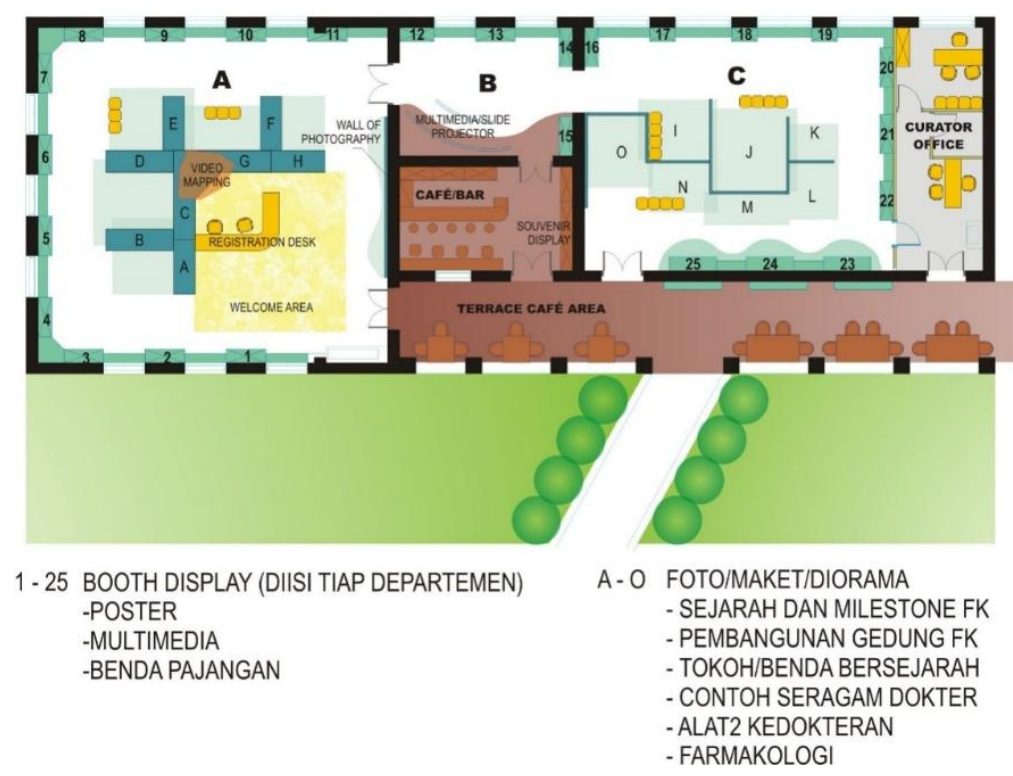

Gambar 6. Rencana Booth/Vitrin Display Museum Mengacu pada Pengaturan Alur Sirkulasi Pengunjung dan Alur Materi Koleksi.

Sumber: Konstruksi Penulis (2016)

Selanjutnya keseluruhan interior museum di bagi dalam 4 ruang besar, mengacu pada eksisting arsitekturnya. Pembagian tersebut sesuai dengan pembabakan materi yang disajikan. Komposisi komponen desain interior disiplin mengacu pada komposisi arsitektur, namun direncanakan memiliki nuansa modern, dramatis dan menyenangkan. Komposisi yang dimaksud meliputi proporsi, garis, bidang, warna dan ornamentasi. Hal yang tidak diikuti oleh desain interior adalah kesamaan material, penghawaan mekanis dan pencahayaan buatan. Hal ini karena kebutuhan akan perubahan fungsi bangunan dan modernisasi dalam operasionalnya. 


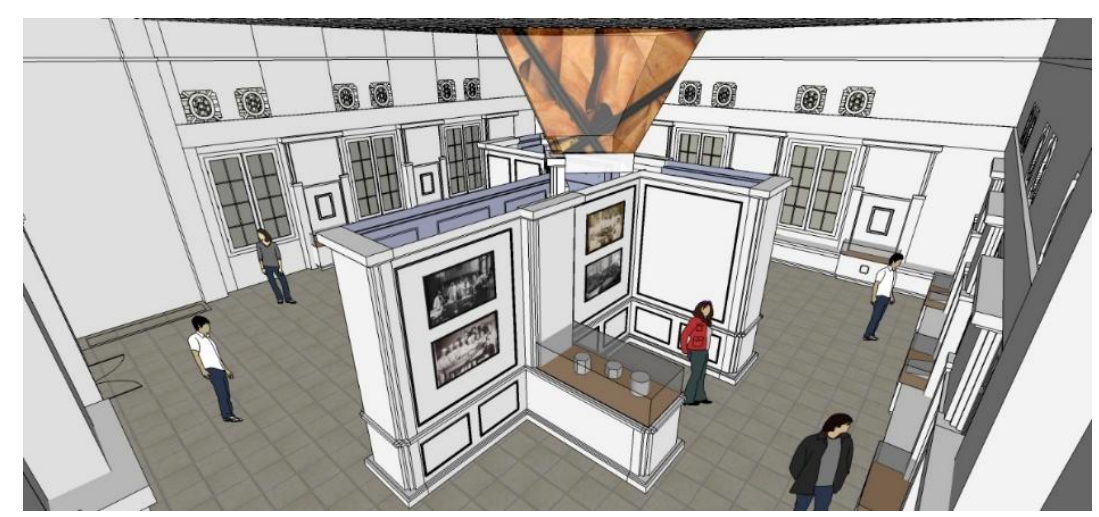

Gambar 7. Sketsa Desain Interior Saat Komposisi Warna Belum Tampak.

Sumber : Dokumentasi Penulis (2013)

Desain interior menghayati komposisi arsitektur eksisting, dan mentransformasikan komposisi tersebut dalam komposisi desain yang lebih modern, sehingga diharapkan dapat dinikmati lebih banyak pengunjung di masa kiwari.

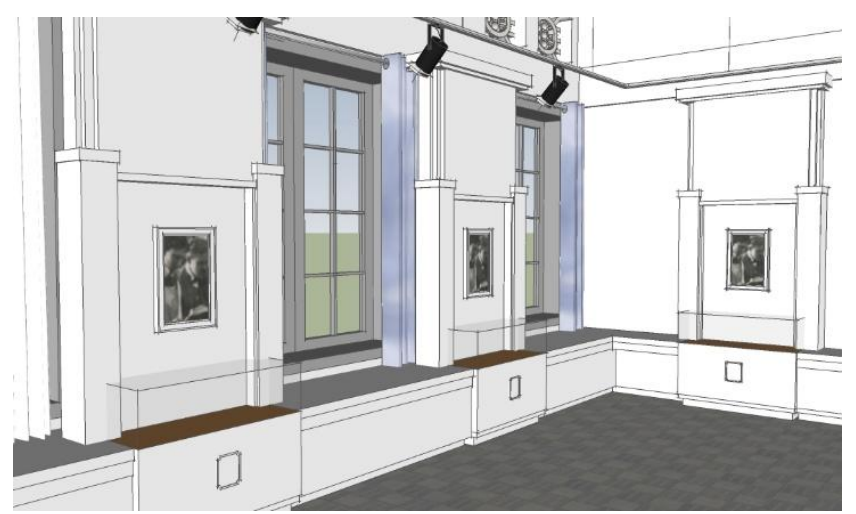

Gambar 8. Sketsa Desain Terukur, Komposisi Arsitektur Eksisting Diacu dengan Transformasi Desain Modern. Sumber : Dokumentasi Penulis (2013)

Booth/vitrin menyesuaikan dimensi jendela eksisting arsitektur. Skema fungsi yang dikemukakan adalah:

1. Bagian kredensa bawah berfungsi sebagai tempat penyimpanan materi yang tidak didisplay.

2. Bagian atas kredensa berfungsi untuk peletakan benda 3 dimensi.

3. Bagian dinding display (multimedia/non multimedia) berfungsi sebagai penyampai materi dalam bahasa visual dan tulisan bergaya modern kontemporer. 
Thomas Ari Kristianto, Caesario Ari Budianto, Prasetyo Wahyudie

Representasi Desain Indisch Trophic dalam Desain Interior Museum Pendidikan Dokter Indonesia di Surabaya

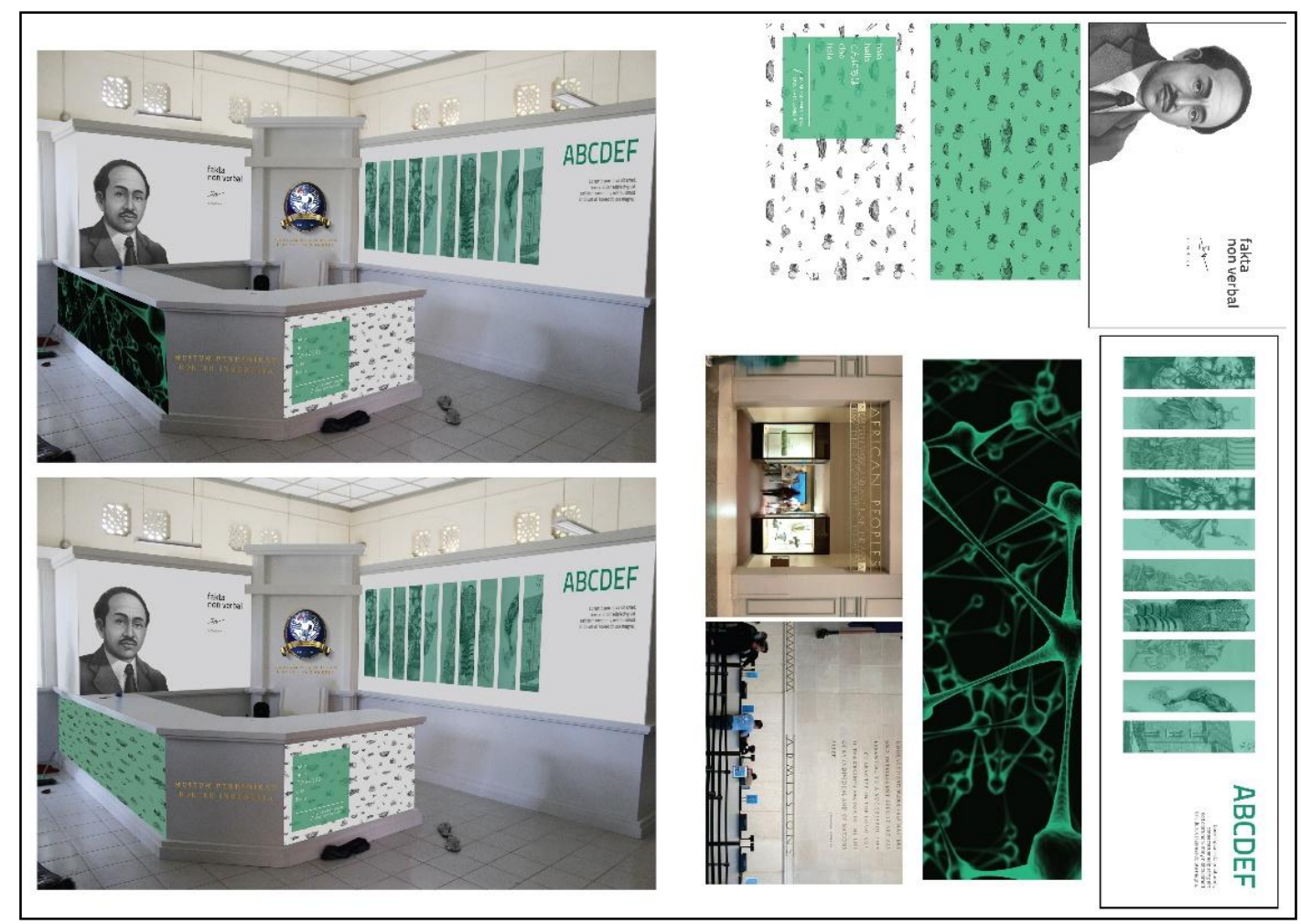

Gambar 9. Desain Display dan Penyampai Informasi Materi Koleksi pada Booth/Vitrin Display. Sumber : Dokumentasi Penulis (2013)

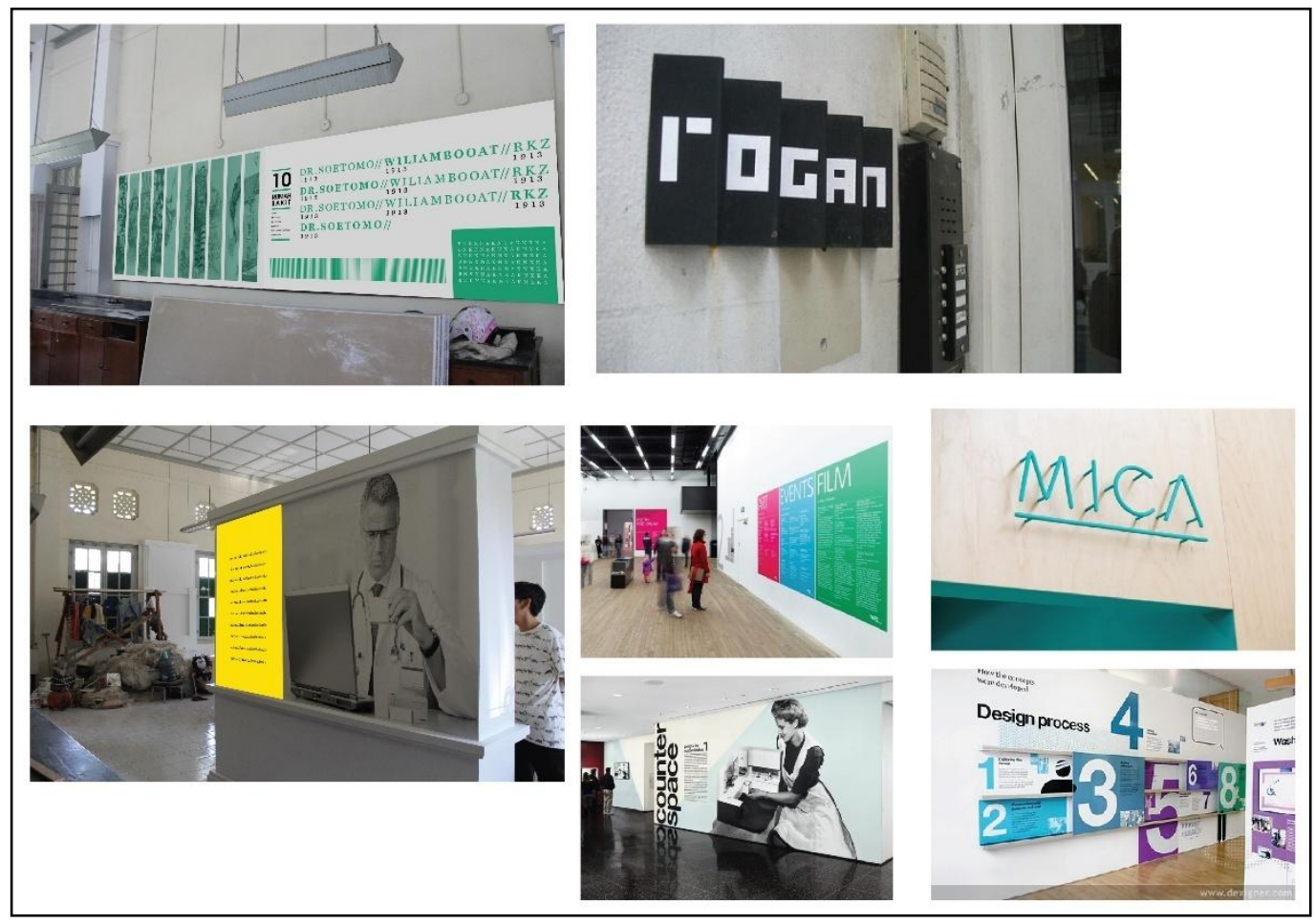

Gambar 10. Desain Metode Penyampai Materi Secara Visual di Bidang Vertikal. Sumber : Dokumentasi Penulis (2013) 


\section{VDINANINIOR}

Vol. 1, No. 2, Desember, 2016, ISSN 2527 - 2853

Pencahayaan direncanakan menggunakan lampu spot LED dengan warna cahaya 6500 kelvin, digantung pada rail track untuk semua koleksi. General lighting berupa lampu TL fluorescent dengan armatur besar digunakan hanya untuk pemeliharaan bangunan.

Penghawaan menggunakan mekanis AC multisplit dengan kapasitas 70\% dari kapasitas BTU yang dibutuhkan volume ruang. Modifikasi spesifikasi ini adalah langkah tidak biasa yang diambil dengan pertimbangan, penghematan daya listrik karena tidak terlalu banyaknya pengunjung dalam operasional hariannya (max 40 orang per sesi). Namun kapasitas AC tersebut masih dapat menjaga suhu ideal dan kelembaban ideal bagi keawetan materi.

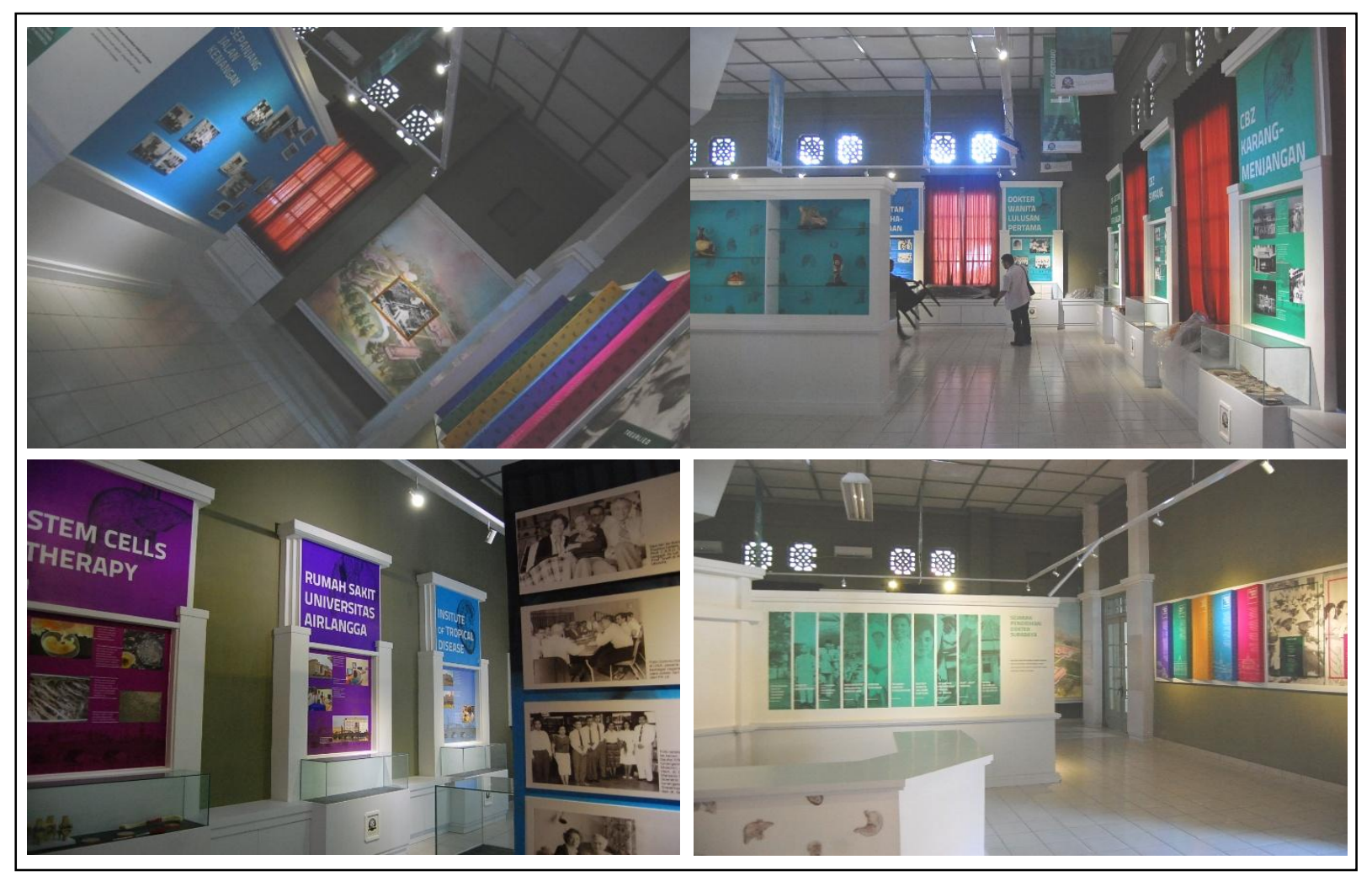

Gambar 11. Rangkaian Hasil Desain Museum. Sumber : Dokumentasi Penulis (2014)

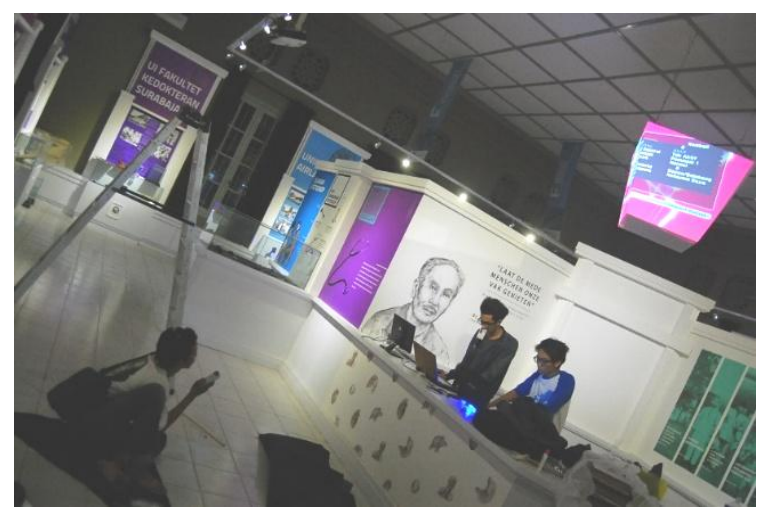

Gambar 12. Penggunaan Layar Multimedia dan Teknik Video Mapping untuk Tampilan Audio Video. Sumber : Dokumentasi Penulis (2014) 


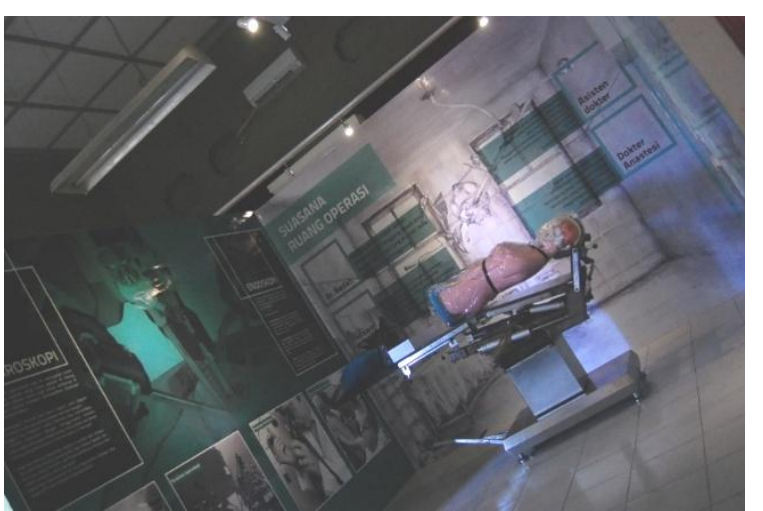

Gambar 14. Model Grafis Informasi Modern Kontemporer pada Booth/Vitrin Ruang Operasi. Sumber : Dokumentasi Penulis (2014)

\section{KESIMPULAN}

Desain museum hendaknya dimulai dari riset materi koleksi. Koleksi, seleksi dan proses kurasi yang tepat akan menentukan komposisi desain interior. Gaya desain dapat beraneka ragam agar pengunjung dapat selalu tertarik, namun hendaknya ada benang merah penyambung konsep desain interior di tiap bagian ruang.

\section{Ucapan Terima Kasih}

1. Panitia 100 tahun FK Unair

2. Fakultas Kedokteran Universitas Airlangga

3. Prof. DR. dr. Indropo Aguzni

4. Prof. DR.dr. Sentot Moestajab Soeatmadji

5. DR. dr. Hendy Hendarto, Sp.OG (K)

6. DR. dr. Purwati, SpPD, (K), FINASIM

7. Museum Kesehatan DR Adhyatma, MPH Surabaya

8. Dr. Poedjo Hartono, Sp.OG., Ikatan Dokter Indonesia

\section{DAFTAR PUSTAKA}

1. Djelantik, A.A.M., (1999), Estetika, Sebuah Pengantar, Media Abadi, Yogyakarta.

2. Malnar, J.M. and Vodvarka, F.,(1992), The Interior Dimension,Van Nostrand Reinhold, New York.

3. Palmer, E.A., (1981), The Architect's Guide to Facility Programming, The American Institute of Architecs, Washington.

4. Pile, J.F., (1997), Color in Interior Design, Mc Graw-Hill, New York.

5. Snyder,'J.C et al., (1997), Pengantar Arsitektur, Erlangga, Jakarta.

6. Stein, B. et al.,(2006), Mechanical and Electrical Equipment for Buildings, John Wiley and Sons, New Jersey.

7. Walker, J.A. ,(1989), Design History and History of Design, Pluto Press, London. 